\title{
The Influence of School Leadership and Supervision of School Heads on Teacher Performance in SMP Negeri Pengandonan Sub-District Ogan Komering Ulu District
}

\author{
Yeliwitri $^{\left.1^{*}\right)}$, Nur Ahyani ${ }^{2}$, Nila Kesumawati ${ }^{2}$ \\ ${ }^{1}$ SMP Negeri 4 Ogan Komering Ulu District, South of Sumatra, Indonesia \\ ${ }^{2}$ Universitas PGRI Palembang, Indonesia \\ *Corresponding author.Email: yeliwitri1707@gmail.com
}

\begin{abstract}
The purpose of this study was to define and evaluate the effect of school principal and school principal supervision variables on teacher efficiency. This is a form of quantitative analysis. The population of this sample was 50 people from SMP Negeri at Pengandon Subdistrict. The data collection methods used were questionnaires, observations, interviews and documentation. The data analysis methodology in this study began with the use of inferential statistics including normality, homogeneity, linearity, simple linear correlation test, multiple correlation test, $\mathrm{T}$ test, and $\mathrm{f}$ test. The findings of this analysis are: (1) the main leadership has a positive impact on the performance of teachers; (2) the main supervision has a positive effect on the performance of teachers; and (3) the main leadership and supervision at the same time have a positive effect on the performance of teachers.
\end{abstract}

Keywords: School Leadership, School Heads, Teacher Performance

\section{INTRODUCTION}

Education is very important because education is a deciding factor in the quality of human capital. Education is the most significant predictor for the growth of a nation [1]. The quality of human resources (HR) has a good relationship with the quality of education. The standard of education is also demonstrated by the fact that it is in good shape, that it meets the criteria and all the components that must be used in education. These components are input, procedure, output, training staff, facilities and costs. Quality of education is achieved if any of these elements play a larger role in the quality of education workers. In the future, the staff of education will be more nuanced, so that the staff of education must still make different changes and modifications to their skills. Quality education also needs the professional workers in education. Educational workers have a very strategic role to play in the teaching of students' awareness, abilities and character. Skilled education workers will also carry out their professional duties in order to deliver higher-quality graduates. Modern education carries the fate of accountability for destructive developments in the moral and spiritual domain of humanity [2]. Becoming a professional educator would not only happen without attempts to develop it. One of the ways to make this possible is by improving professionalism. This needs the cooperation of parties that have an important role, in this case the school principal. The Principal should be able to carry out innovations and be able to lead all stakeholders and the school as an educational institution [3]. Where the Principal is a very significant leader in education, since the Principal is directly linked to the implementation of educational programs in schools.

The achievement of educational objectives is highly dependent on the leadership abilities and wisdom of the principal. The style of leadership embraced by the Principal would be connected to the results and success of the Principal in guiding and executing the school education process [4]. Since the principal is a competent school official who is in charge of handling all organizational resources and working with teachers to educate students and achieve educational objectives. The creation of educational staff is easy with the leadership of this school principal, since it is in line with their role. The Principal understands the needs of the school he leads in such a way that the skill of the teacher does not end at the competencies he previously had, but changes and grows well enough that the professionalism of the teacher is realized. Leadership is one of the factors that decide the progress of the 
creation of a harmonious school community. The principal, as the person in charge of the educational institution he heads, has a daunting job. The explanation for the good and the bad of these institutions cannot be removed from the oversight of the principal of the school. Supervision is one of the duties of educational administration, which seeks to ensure and promote the smooth, effective and productive running of teaching and learning activities in schools in compliance with relevant laws and regulations. With the proper functioning of leadership management, it is expected that the institutions they lead will witness the growth and enhancement of the standard of education [5].

Another description according to Revisoned Baswir in his book Accounting for the Government of Indonesia notes that the objective of the Principal in the conduct of supervisory activities is to obtain assurance as to whether the execution of a job or operation is carried out in compliance with the plans, rules and objectives that have been set out [6]. Supervisory measures are necessary and enforced by any formal and non-formal entity.

In the administration and management of education, in particular teaching and learning practices in schools, supervision of instruction for the achievement of educational objectives must be carried out. The principal in the exercise of his authority must concentrate more on the employees of the school, in particular the students, since the teacher is the direct implementer of teaching and learning activities. The monitoring carried out by the Principal has a very strong impact on enhancing the performance of the teacher so that it becomes quality. Continuous supervision by the Principal can encourage teachers to improve their performance in the teaching and learning process to become quality. Essentially, the Principal serves three roles, namely, helping teachers to understand, pick and formulate educational objectives to be accomplished, mobilizing teachers, workers, students and community members to succeed in school education initiatives and establishing schools as a work environment. This is harmonious, balanced, dynamic and relaxed so that all participants can work with maximum productivity and achieve high efficiency.

Performance can be defined as the achievement of the results of work in compliance with the rules and standards that apply to each organisation, in this case the school. As an educator, the Principal must be able to impart, encourage and improve emotional, spiritual, physical and creative principles to teachers or other staff members, administrative staff (staff) and groups of students or students. To instill this position, the Principal must demonstrate a convincing and exemplary attitude. This convincing and exemplary attitude would characterize the administration, including the supervision of the principal of the school's teachers.
The principal as an educator, supervisor, motivator who must coach employees and teachers in the school they lead because human factors are the central factor that determines the entire movement of an organization's activities, even though the technology used is so sophisticated, it remains the human factor that determines it. In its role as a driving force for teachers, school principals must be able to mobilize teachers in order to increase their performance, because teachers are the driving force behind the creation of quality human beings. Essentially, the teacher will work optimally if the principal oversees the performance of the teachers at the school. As a result, the teacher will feel cared for and the teacher will always try to improve the performance of teaching, in addition to other factors that also affect the performance of the teacher. The aim of this study was to identify and describe the influence of the Principal's leadership on the performance of teachers in SMP Negeri at Pengandon Subdistrict.

To find out and describe the effect of supervision on the performance of teachers at SMP Negeri at Pengandon Subdistrict. To find out and describe the influence of the Principal's leadership and supervision of the teaching staff of the SMP Negeri at Pengandon Subdistrict. Leadership is a part of governance [7]. Leadership plays a dominant, crucial and critical role in the overall effort to increase work productivity, both at the individual level, at the group level and at the organizational level. In this case, there are many experts who are trying to define leadership [8]. According to Nasution [7], in his book Educational Leadership, he argues that leadership is the capacity and readiness that a person must be able to influence, encourage, invite, guide, mobilize and, if necessary, force others to accept that influence and then do something that can help to achieve some intention. Or specific objectives.

The Principal is a functional staff assigned to lead an educational institution (school) in which the teaching and learning process takes place [9]. Principal leadership is the way or effort of the Principal to influence, encourage, guide, direct and mobilize teachers, staff, students, parents and related parties to work or to play a role in achieving the objectives set [10].

Leadership has been born since humans existed, but when it comes to leadership, it's a fascinating subject and it's not going to be debated endlessly. So leadership research draws a lot of scientists to do this. A variety of viewpoints and types of leadership have developed from the findings of the study. Leadership as a process of persuading (inducing) others to take action towards a shared objective. The concept is categorized as three components. First of all, leadership is a relational term. Leadership occurs only in interactions with other citizens. Second, the process of leadership is a process [11]. The leader has to do anything to lead. Leader must 
have the ability to make decisions accurately and quickly on the basis of reasonable and mature considerations [12]. The principal is a functional teacher who is assigned the additional task of leading a school where teaching and learning are carried out. In carrying out the duties and leadership roles of the Principal, the Principal must have the capacity to mobilize, mobilize, direct, defend, promote, exemplify, facilitate and assist all human capital in the school so that they can be used as much as possible to achieve the objectives. It has been set [9].

Supervision tracks the work of workers in order to keep the company going towards the achievement of targets and, if necessary, to make corrections [8]. Supervision is the method of assessing performance metrics in the course of action that will facilitate the achievement of the desired outcomes according to the predetermined measures [13]. Supervision is a mechanism in which the supervisor needs to know the outcomes of the work carried out by the subordinates in accordance with the plans, orders, goals and policies that have been established [14]. Supervision is a standard setting, assessment of implementation and corrective action [15]. Management oversight is a systematic effort to set standards for implementation with planning goals, to design an input information system, to compare actual operations with predetermined standards, to detect and quantify anomalies, and to take corrective action to ensure that all sources of power have been used in the most effective and efficient manner to achieve organizational objectives [15].

Supervisory measures are necessary and enforced by any formal and non-formal entity. Academic monitoring is a coaching practice by offering professional support to teachers in the learning process. Teachers are a profession whose job is to carry out education in an elementary and high school by using various learning methods to meet their learning targets [16]. The aim is to develop the professional skills of teachers and to improve the standard of learning. Academic monitoring should be carried out through a clinical supervision approach that is carried out consistently by preobservation, learning observation and post-observation stages [17]. "Performance" means the execution of an operation (Webster New Collegiate Dictionary). Success may be said to be a success, a demonstration of the action to be taken in carrying out the activities or tasks to be carried out [16].

\section{METHODS}

The research method is a way of working to collect data and then process data to create data that can solve research problems. The task of research methodology is very critical in the effort to gather the data required for research, in other words, the research method will provide guidance on the implementation of research or guidance on how this research is carried out [18]. Methodology includes meaning that concerns the procedures and methods for evaluating the data required to solve or respond to research problems. This study uses a quantitative descriptive approach with a correlational style of research. Quantitative methods can be described as a research method based on the philosophy of positivism used for research on certain populations or samples, data collection using research instruments, quantitative/statistical data analysis with the goal of testing the existing hypothesis [19]. The use of quantitative descriptive methods is consistent with the research variables that define the real problems and phenomena that are occurring at the moment in the form of research findings in the form of numbers that have significance.

The population of this study was 2 teachers in the SMP Negeri at Pengandon Subdistrict, totalling 2, namely SMP Negeri 28 OKU 20 teachers and SMP 04 Negeri OKU 30 teachers. The sampling technique used in this study was Total Sampling or Total Popuasi, which brought together a total of 50 teachers who were actively teaching at school and enrolled in the SMP Negeri of Pengandon Ogan Komering Ulu District, totalling 2 SMP, namely SMP Negeri 28 OKU and SMP Negeri 04 OKU. The data collection method used in this study is a survey or analysis technique that is carried out directly on the field using a questionnaire/questionnaire data collection tool by direct interviews with respondents. The data analysis methodology used simple and multiple linear regression tests in this study. Prerequisite tests were carried out prior to the analysis of the results, namely the normality test, the linearity test and the multicollinearity test.

\section{RESULTS AND DISCUSSION}

Results of survey respondents related to the leadership style of school principals in SMP Negeri all Pengandonan District, namely 9 respondents (18\%) rated the category as very good, 21 respondents $(42 \%)$ rated it as good, 15 respondents $(30 \%)$ rated it as very good. Very strong, and 5 respondents $(10 \%)$ ranked it in the lower group.

Oversight variables in this study were assessed by 35 statement items related to the orientation of the supervision function, the implementation of supervision concepts, supervision methods, academic supervision objectives, and follow-up supervision based on questionnaire responses from 50 respondents to the SMP Negeri Pengandonan Sub-District. The mean value is 120.76 , the mean value is 120.00 and the mode value is 118 , the minimum value is 115 and the maximum value is 131 . The overall image of the monitoring variable data $\left(X_{2}\right)$ is taken from a total of 4589 with a score range of 16 with an empiric range between scores 
115 and 131. Based on the results of the data processing carried out, the average was 120,76 ; mean 120,00; mode 118 with a standard deviation of 3,308 .

The Respondent's evaluation of the supervision carried out by the Principal in SMP Negeri all Pengandonan District, namely 2 respondents (5.3\%) considered the category to be quite good, 14 respondents $(36.8 \%)$ rated it as good, 18 respondents $(47.4 \%)$ rated the category as very good, and 4 respondents $(10.5 \%)$ rated it as poor. The overall classification of the performance variable data of SMP Negeri teachers in the Pengandonan (Y) District is 69.95; Medium 70.00; mode 67 with a standard deviation of 2,875 .

Respondents' assessment of their success as teachers in the SMP Negeri Pengandonan Districts, namely 15 respondents $(30 \%)$ rated them as very good, 18 respondents $(36 \%)$ rated them as good, 14 respondents (23\%) rated them as good, and 3 respondents $(6 \%)$ rated them less. The meaning of the Kolmogorov-Smirnov test for the instructor efficiency variable (Y) is 0.190 , which is greater than $0.05(0.190>0.05)$, the value of Sig. For the control variable $\left(\mathrm{X}_{2}\right)$ of 0.200 , which is greater than $0.05(0.200>0.05)$, And the Sig, too. For the key leadership component $\left(\mathrm{X}_{1}\right)$ of 0.062 , which is also greater than $0.05(0.062>0.05)$. Because of the Sig. > 0.05 , then H0 (zero hypothesis) is acknowledged, so it can be stated that the data is normally distributed.

The $\mathrm{X}_{1}-\mathrm{Y}$ pair had a $\mathrm{F}$ Deviation from Linearity of 1.633 with $\mathrm{p}=0.152>0.05$. Thus, it can be claimed that the relationship between $\mathrm{Y}$ and $\mathrm{X}_{1}$ is linear. The $\mathrm{X} 2-\mathrm{Y}$ pair had a F Deviation from Linearity of 1.223 with $\mathrm{p}=0.322>0.05$. Thus, it can be claimed that the relationship between $\mathrm{Y}$ and $\mathrm{X} 2$ is linear. The value of the VIF is similar to 1 for all independent variables. Likewise, the tolerance value is approached by 1 for all independent variables. Thus, it can be assumed that there is no multi-collinearity between the independent variables key guidance $\left(\mathrm{X}_{1}\right)$ and supervision $\left(\mathrm{X}_{2}\right)$ between the independent variables.

The results of the regression analysis showed that the $\mathrm{t}$ count value was $11.252>\mathrm{t}$ Table 2.042 and the significance value (Sig.) Of $0.000<0.5$, it can be claimed that $\mathrm{H} 0$ is rejected and $\mathrm{H} 1$ is accepted. It can therefore be inferred that the supervision of the Principal $\left(\mathrm{X}_{2}\right)$ has an impact on the output of the teachers of the SMP Negeri Pengandonan Districts (Y). This is dependent on the decision made in the $t$ test, i.e. $\mathrm{H} 0$ is rejected and $\mathrm{H} 1$ is accepted if the $\mathrm{t}$ value is $>\mathrm{t}$ table value or the Sig value is accepted. $<0.05$ a.m. The regression that is being sought is the meaning of Sig. $00.00<0.05$. Thus, it can be inferred that the value in column B is important, which means that the correct equation for the two variables is $\mathrm{Y}=22,676+0,767 \mathrm{X}_{2}$. $\mathrm{R}$ Square is 0.779 of the correlation coefficient $(\mathrm{R})$ of 0.882 . This means that $77.9 \%$ of the success of SMP
Negeri teachers in the Pengandon District is determined by the supervision of the school principal. The remaining $22.1 \%$ were affected by other variables.

The results of the regression analysis showed that the tcount value was $3.352>2.042$ ttable value and the significance value (Sig.) was $0.002<0.05$, it can be claimed that $\mathrm{H} 0$ is rejected and $\mathrm{H} 1$ is accepted. It can therefore be inferred that the leadership of the Principal $\left(\mathrm{X}_{2}\right)$ has an effect on the success of SMP Negeri Pengandonan District (Y) students. The Sig is the regression being searched. $0.002<0.05$. Please. It can therefore be inferred that the value in column $\mathrm{B}$ in table 41 is important, which means that the most suitable equation for the two variables is $\mathrm{Y}=10.803+0.670 \mathrm{X}_{2}$. $\mathrm{R}$ Square is 0.238 of the correlation coefficient $(\mathrm{R})$ of 0.488 . Thus, it can be argued that $23.8 \%$ of the success of the SMP Negeri Pengandonan Districts is affected by the leadership shown by the Principal. While the remaining 76.2 percent is affected by other factors.

Another factor in question is that there are open questions about the basic items that affect their success as teachers 3 people (7.9\%) answered the factor of accuracy of the disbursement of the professional allowance for teachers (certification), 4 people $(10.5 \%)$ responded to the factor of strength of their participation in the workshop, technical guidance as well as related education and training. The mean value for the $\mathrm{Y}$ variable with a standard deviation of 2,875 is 69.95 . The average value for the lead variable of the principal was 120.76 with a standard deviation of 3.308 . The mean value of the control variable is 88.32 with a standard deviation of 2.094

The results of the study show a constant price of 22,611 with a leadership variable coefficient of 0,767 , and a monitoring variable of 0,001 . The two vector coefficient values have different significance levels of 0.842 and 0.002 , respectively. A significant group according to the F test earned a score of 61,540 with a significance level of 0.000 . The results of the regression analysis showed that the Fcount value was $61.540>$ The Ftable value was 3.26 for the 5 percent significance level and the Ftable value was 5.25 for the $1 \%$ significance level. A significance value (Sig.) of 0.000 $<0.05$ was also obtained. Note that the Fcount value is greater than the Ftable value and the Sig value. Less than 0.05 , it can be claimed that $\mathrm{H} 0$ is rejected and $\mathrm{H} 1$ is accepted. Thus, it can be inferred that Principal Leadership $\left(\mathrm{X}_{1}\right)$ and Supervision $\left(\mathrm{X}_{2}\right)$ simultaneously influence the performance of SMP Negeri Teachers in the Pengandon District (Y).

\section{CONCLUSION}

On the basis of the study data and the findings of the data review carried out by the researcher, it can be concluded that: 1) the supervision of the principal has an 
impact on the output of the teachers of SMP Negeri in the Pengandonan District, where the $t_{\text {count }}$ value is $11.252>t_{\text {table }} 2.042$ and the significance value (Sig.) $0.000<0.05$. Thus, it can be inferred that $\mathrm{H}_{0}$ is rejected and $\mathrm{H} 1$ is approved, meaning that supervision $\left(\mathrm{X}_{1}\right)$ affects the performance of teachers (Y). The contribution of primary supervision to the success of teachers is $77.9 \%$. This means that the better implementation of school principal academic supervision appears to improve the professionalism of Islamic education teachers in the performance of their professional duties, while the remaining $22.1 \%$ is affected by other factors; 2) the impact of the principal's leadership on the performance of teachers with a $\mathrm{t}_{\text {count }}$ value of $3.352>2.042 \mathrm{t}_{\text {table }}$ va Thus, it can be inferred that $\mathrm{H}_{0}$ is rejected and $\mathrm{H}_{1}$ is approved, meaning that the leadership of the Principal $\left(\mathrm{X}_{2}\right)$ affects the performance of the teacher (Y). Meanwhile, the principal's contribution to the success teachers of SMP Negeri in the Pengandon District was 23.8\%. This means that the more successful the leadership of the Principal appears to increase the performance of teachers in the performance of their professional duties, while the remaining $76.2 \%$ is affected by other factors, 3) there is an impact of supervision and leadership of the Principal on the performance of teachers in the SMP Negeri Se-Pengandon District, where the data shows a constant price. The $X_{1}$ and $X_{2}$ partial correlations were 0.842 and 0.002 respectively. The magnitude of the effect of the supervision of the Principal and the leadership of the Principal at the same time on the results of the SMP Negeri Pengandonan Districts is $88.2 \%$.

\section{ACKNOWLEDGMENTS}

The author would like to thank Dr. H. Bukman Lian, M.M., M.Si., Chancellor of the PGRI Palembang University, Dr. Syaiful Eddy, M.Sc., Director of the Postgraduate Program at the PGRI Palembang University, Dr. Happy Fitria, M.Pd., Head of Education Management Study Program and all those who have helped morally and materially. May the goodness become multiple good deed.

\section{REFERENCES}

Rahmadoni, J., Arifnur, A. A., \& Wahyuni, U. M. (2020). Penerapan Schoology Sebagai Learning Management System Bagi Guru SMAN 1 Sutera [Implementation of Schoology as a Learning Management System for Teachers of SMAN 1 Sutera]. Jurnal Hilirisasi IPTEKS volume 3 No 2.

[1] Asvio, N., Yamin, M., \& Risnita. (2019). Influence of Leadership Style, Emotional Intelligence and Job Satisfaction toward Organizational Commitment (Survey at SMA Muhammadiyah
South Sumatera). International Journal of Scientific \& Technology Research 8 (8).

[2] Maseleno, A., Ayshwary, B., Ivanova, T. N., Hashim, W., Nguyen, P. T., Shankar, K., Kristiawan, M., Huda, M. (2019). General Theoretical and Philosophical Aspects of Modern Education. Aspectos Teóricos y Filosóficos Generales de la Educación Moderna. Revista San Gregorio 2019, No. 32 Special Issues August.

[3] Andriani, S., Kesumawati, N., \& Kristiawan, M. (2018). The Influence of the Transformational Leadership and Work Motivation on Teachers Performance. International Journal of Scientific \& Technology Research, 7(7).

[4] Astuti, R. W., Fitria, H., \& Rohana, R. (2020). The Influence of Leadership Styles and Work Motivation on Teacher's Performance. Journal of Social Work and Science Education, 1(2), 105-114. Retrieved from https://ejournal.karinosseff.org/index.php/jswse/arti cle/view/33

[5] Hendriyadi, Ritonga, A. H., \& Us, K. A. (2020). Management Leadership in Improving the Quality of Graduates of Private Islamic Religious Colleges in Jambi Province. International Journal of Progressive Sciences and Technologies (IJPSAT) Vol. 23 No. 2 November 2020, pp. 42-51 Retrieved from https://ijpsat.ijshtjournals.org/index.php/ijpsat/article/view/2308

[6] Baswir, R. (1999). Akuntansi Pemerintahan Indonesia Edisi Tiga [Indonesian Government Accounting Edition Three]. Yogyakarta: BPFE.

[7] Nasution. (2005). Total Quality Management. Jakarta: PT Gramedia Pustaka Utama.

[8] Siagian, P. S. (2002). Fungsi-Fungsi Manajerial [Managerial Functions]. Jakarta: Bumi Aksara.

[9] Wahjosumidjo. (2014). Kepemimpinan Kepala Sekolah, Tinjauan Teoritik dan Permasalahannya [Principal Leadership, Theoretical Review and Its Problems]. Jakarta: Raja Grafindo Persada.

[10] Munir, A. (2008). Menjadi Kepala Sekolah Efektif [Become an Effective School Principal]. Jogjakarta: Ar ruzz

[11] Locke. (2015). Essensi Kepemimpinan [The Essence of Leadership]. Jakarta: Spektrum.

[12] Mukhtar, Yamin, M., \& Nurzen, S. S. (2020). The Influence of Academic Culture, Management Knowledge and Interpersonal Communication on Decision Making by the Head of Private Islamic Colleges in Jambi Province. International Journal 
of Progressive Sciences and Technologies (IJPSAT) Vol. 23 No. 2 November 2020, pp. 09-19.

[13] Ernie, T. D. (2005). Pengantar Manajemen [Introduction to Management]. Jakarta: Kencana.

[14] Simbolon, M. M. (2004). Dasar-dasar Administrasi dan Manajemen [Administration and Management Basics]. Jakarta: Ghalia Indonesia.

[15] Handoko. (2003). Manajemen. Edisi 2 [Management]. Cetakan ke 18. Yogyakarta: BPFE.

[16] Rahmatika, D. F., \& Ratnasari, N. (2018). Media Pembelajaran Matematika Bilingual Berbasis Sparkol Videoscribe [Bilingual Mathematics Learning Media Based on Videoscribe Sparkol]. Desimal: Jurnal Matematika, 1(3), 385393.

[17] Suharsaputra, U. (2013). Administrasi Pendidikan, Edisi Revisi [Educational Administration, Revised Edition]. Bandung: PT Refika Aditama.

18] Surakhmad. (2004). Pengantar Penelitian Ilmiah, Dasar, Metode, dan. Teknik [Introduction to Scientific Research, Basics, Methods, and. Technique]. Bandung: Tarsit.

[19] Sugiyono. (2019). Metode Penelitian Kuantitatif Kualitatif dan $R \& D$ [Qualitative and Quantitative Research Methods $R \& D$ ]. Bandung: Alfabeta. 